\title{
Reactive Lymphocyte
}

National Cancer Institute

\section{Source}

National Cancer Institute. Reactive Lymphocyte. NCI Thesaurus. Code C12847.

A type of white blood cell that enlarges in response to antigenic stimulation. 